\title{
Linear body and reproductive organ characteristics of West African Dwarf goats fed groundnut haulms and cowpea husk with brewers dried grain supplement
}

\begin{abstract}
A study was conducted to determine the effects of feeding groundnut haulms, and cowpea husk supplemented with brewers' dried grain on variability in body Morphometric measurements and the reproductive organ characteristics of West African Dwarf goats. Body parameters measured were body length (BL), heights at withers (HW), girth circumference (GC), Height at rump (HR), abdominal circumference (AC) neck length (NL), neck circumference (NC) with live weights of animals. Reproductive organ parameters determined were scrotal length (SL), scrotal circumference (SC), Scrotal and testicular weight (STW), Testicular circumference (TC), Testicular volume (TV), penile length (PL) and (PW) penile weight. The ranges for the parameters were length of animal (LA) 30.33 to $38.92 \mathrm{~cm}$, height at rump (HR) 28.25 to $39.71 \mathrm{~cm}$, abdominal circumference (AC) 18.79 to $22.29 \mathrm{~cm}$ and neck length of 13.46 to $17.79 \mathrm{~cm}$. All the results were significantly $(\mathrm{P}<0.05)$ different across treatments. The reproductive organ parameters, scrotal circumference and testicular parameters were measured with caliper and tape. Results revealed that ranges were scrotal lengths (SL) varying from 27.38 to $38.92 \mathrm{~cm}$, Scrotal circumference (SC) 12.67 to $17.63 \mathrm{~cm}$, Scrotal and testicular weights (STW) from 36.92 to $45.67 \mathrm{~g}$, Testicular volumes 17.88 to 21.08 $\mathrm{mls}$ while for penile morphometry, the results ranged from 3.06 to $4.13 \mathrm{~cm}$ for penile length (PL) and 3.21 to $3.79 \mathrm{~g}$ for penile weights respectively. All parameters differed $(\mathrm{P}<0.05)$ significantly across treatments. It was concluded that the reproductive organ parameters especially scrotal circumference are useful indicators and important selection criteria to determine the reproductive organs development and breeding soundness in young animals. That, there is variability in body measurements and that these measurements can be exploited in predicting live body weight and hence the economic value of goats.
\end{abstract}

Keywords: live body weight, linear traits, reproductive organs, goats
Volume 5 Issue 5 - 2018

\author{
Babale DM,' Millam JJ,' Hassan HY,' Kefas \\ $\mathrm{BW}^{2}$ \\ 'Department of Animal Production, Adamawa State University, \\ Nigeria \\ ${ }^{2}$ Government Secondary School, Gashala, Hong Loca \\ Government, Nigeria
}

Correspondence: Babale DM, Department of Animal Production, Adamawa State University, Mubi, Nigeria, Te 07033749171,07088|47216, babaled@yahoo.com

Received: August 17,2018 | Published:September 24, 2018
Abbreviations: BL, body length; HW, heights at withers; GC, girth circumference; HR, Height at rump; AC, abdominal circumference; NL, neck length; NC, neck circumference; SL, scrotal length; SC, scrotal circumference; STW, scrotal and testicular weight; $\mathrm{TC}$, testicular circumference; TV, testicular volume; PL, penile length; $\mathrm{PW}$, penile weight

\section{Introduction}

Body dimensions in different livestock species have been studied by many scientists. Therefore the assessments of the powers of body measurements in the estimation of weights and the accuracy of body weights in the estimation of size have been reported. ${ }^{1}$ The ability of the producers and buyers to relate the live animal measurements to growth characteristics is essential for optimum production and value based trading system. ${ }^{2}$

According to Akpa et al. ${ }^{3}$ growth is the sum total of increase in size of different structural body components measured from gain in body weight and linear body measurements. Adewumi \& Adewole ${ }^{4}$ also stated that the ability of the producers and buyers of livestock to relate live animal measurements to live weights is of immense financial contribution to livestock production enterprise. Bello \& Adama $^{5}$ reported positive significant $(\mathrm{P}<0.01)$ difference between neck length and height at withers $(\mathrm{r}=0.750)$, hind leg length and foreleg length $(\mathrm{r}=0.560)$ body weight and chest girth $(\mathrm{r}=0.677)$.

Reproduction is one of the most important factors for the economics of livestock production. Perumal ${ }^{6}$ reported that testicular measurements at early ages are very important in selection of breeding sires to collect semen for artificial insemination (A.I). The important parameters of testicular measurements are diameter, length, volume and circumference. ${ }^{7}$ Kaymakci et al. ${ }^{8}$ stated that male animals with bigger testes produce more sperm than males with smaller testes. Salhab et al. ${ }^{7}$ further reported that testicular size is positively related to body weight and age. Scrotal circumference is reported to be highly $(\mathrm{P}<0.01)$ correlated with body weight and age ${ }^{9}$ and highly $(\mathrm{P}<0.01)$ correlated with testes weight, ${ }^{10}$ consistency and fertility. ${ }^{11}$

It is reported by Jennifer ${ }^{12}$ that scrotal circumference is an indicator of a bull's fertility. The author further stated that hip height is used to measure expected progeny difference for mature weight. The larger the bull's scrotal circumference, the earlier its daughters will reach puberty. ${ }^{13}$ Scrotal size correlates well with daily sperm production. ${ }^{14}$ Bull with bigger testicles produce more semen, sire sons with bigger testicles and reach puberty at early age. Differences in scrotal circumference are reflected in the average size of the animal's scrotum. ${ }^{15}$ 
Nutrition has a dramatic effect on testicle size. ${ }^{9}$ Improving nutritional intake during few months before breeding, increases testicular size and sperm production up to $100 \% .{ }^{8}$ The source further reported that scrotal circumference is an indication of breeding ability. That sperm production is directly correlated to testicular width. The measurable criteria for judging breeding soundness of males include scrotal circumference, libido and sperm quality tests. ${ }^{16}$ That ram lambs with less than $30 \mathrm{~cm}$ and adult with $32 \mathrm{~cm}$ testicular circumference should not be used for breeding.

Measure of scrotal circumference is an indirect estimate of the mass of testicular tissue which is directly related to sperm quality and quantity. Martin \& Greef ${ }^{17}$ reported that changes in nutrition of mature rams and bucks led to profound responses in testicular size and therefore rate of production of sperm. Duguma et al. ${ }^{18}$ reported that substandard nutrition can reduce scrotal circumference, testicular mass and hence sperm quality and quantity. Sperm output depends on quantity of sperm stored in the caudal epididymis in the scrotum. The higher the testicular mass, the higher the scrotal circumference and hence higher the sperm quality. ${ }^{19}$

Information on the Morphometric and reproductive organ characteristics of West African Dwarf goats fed these diets is scanty. The study was therefore carried out to determine the linear body measurements, live weights and reproductive organic characteristics of West African Dwarf goats and how they are affected by the diets.

\section{Methodology}

\section{Experimental site}

The research was carried out in Mubi, Adamawa State, Nigeria. Mubi region lies on Latitude $90^{\circ} 11^{\mathrm{I}}$ north of the equator and Longitude $13^{\circ} 45^{\mathrm{I}}$ east of the Greenwich Meridian at an altitude of $696 \mathrm{~m}$ above sea level. It is bounded in the South and East by Republic of Cameroun. With land area of $4,728.77 \mathrm{~m}^{2}$ and population of $245,460,{ }^{20}$ it is situated in the Sudan Savanna zone of Nigeria. The vegetation type is best described as Combretacious woodland savanna ${ }^{21}$ which consists of grasses or weeds and shrubs collectively making $70 \%$ of the entire vegetation. Some of these grasses, weeds and shrubs are used as animal feeds.

The area has two distinct seasons. Rainy season lasts for four (4) months and dry season that lasts for eight (8) months. Annual rainfall ranges from $700-900 \mathrm{~mm}$ with peak in August. The area has minimum temperature of $12.7^{\circ} \mathrm{C}$ in January and maximum of $37^{\circ} \mathrm{C}$ in April. ${ }^{22}$

\section{Sources of feeds}

Groundnut haulms and Cowpea husks were obtained from local farmers' farms after harvest. Brewers' dried grains were purchased from local brewers' in and around Mubi town, Adamawa State, Nigeria. They were bagged and stored.

\section{Experimental animals and their management}

Twelve West African Dwarf bucks of average age of 12 months and mean live weight of $12 \mathrm{~kg}$ were sourced from the local markets in and around Mubi. Their ages were determined through their dental formulae. They were then housed individually in pens measuring $1.5 \mathrm{~m}^{2}$ and $1.5 \mathrm{~m}$ high. The floor of the house was of concrete and covered with wood shavings to absorb moisture from the animals' dung and urine.

The animals were quarantined for two weeks during which they were fed the experimental diets for adaptation and dewormed with
Albendazol. At the end of the adaptation period, the animals were tagged, randomly allocated to treatments and balanced on weight basis for all the treatments. They were weighed to get the initial weights and balanced on weight basis before embarking on data collection.

\section{Experimental diets}

In table one, are presented the experimental diets with groundnut haulms and cowpea husk combined at different levels. The experimental diets were combinations of groundnut haulms at 20,40, 60 and $80 \%$ with cowpea husks at $80,60,40$ and $20 \%$ designated as treatments $\mathrm{T}_{1}, \mathrm{~T}_{2}, \mathrm{~T}_{3}$ and $\mathrm{T}_{4}$ respectively. These combinations were fed ad libitum as basal diets while the Brewers' dried grain (BDG) which served as supplement was fed at $200 \mathrm{~g}$ to all animals across treatments (Table 1).

Table I Experimental diets

\begin{tabular}{lllll}
\hline \multirow{2}{*}{ Feed } & \multicolumn{3}{c}{ Treatments } \\
\cline { 2 - 5 } & $\mathbf{T}_{\mathbf{1}}$ & $\mathbf{T}_{\mathbf{2}}$ & $\mathbf{T}_{3}$ & $\mathbf{T}_{\mathbf{4}}$ \\
\hline GNH (\%) & 20 & 40 & 60 & 80 \\
CPH (\%) & 80 & 60 & 40 & 20 \\
BDG (g) & 200 & 200 & 200 & 200
\end{tabular}

GNH, groundnut haulms; CPH, cowpea husk; BDG, brewers' dried grains

\section{Parameters determined}

Body parameters measured were body length (BL), heights at withers (HW), girth circumference (GC), Height at rump (HR), abdominal circumference (AC) neck length (NL), neck circumference (NC) with live weights of animals. Reproductive organ parameters determined were scrotal length (SL), scrotal circumference (SC), Scrotal and testicular weight (STW), Testicular circumference (TC), Testicular volume (TV), penile length (PL) and (PW) penile weight.

Live weight of each animal was determined by suspending the animal on a spring balance and weight of each animal taken and recorded. In determining body measurements, body length (BL) was measured using tape rule as the distance from the occipital protuberance to the base of the tail.

Height at wither was obtained by using platform upon which each animal was placed. It was measured as the distance from the surface of the platform to the withers using a meter rule. Girth circumference was determined by taking the measurement of the circumference of the chest with a tape. Height at rump was measured as the distance from the surface of the platform to the rump using a measuring rule.

Neck length was the distance from the lower jaw to the point of the shoulder using tape rule. Neck circumference was gotten by measuring the distance round the neck below the lower jaw using the tape rule.

Scrotal circumference was measured by holding the testicles to the bottom of the scrotal sack and placing the tape around the widest point. Testicular length was measured with a tape by manipulating the testes to obtain the distance between the distal and proximal poles of the testes avoiding the capus and cauda of the epididymis. Testes width was measured using veneer caliper at the same point of the scrotal circumference. Paired testes volume was determined by water displacement using a 500mls glass beaker. Scrotal and testicular weight was determined by weighing intact testis in the scrotum. Penile 
length and weights were determined by slaughtering two animals from each treatment, having each penis measured with tape rule to obtain penile length, and weighing scale to obtain penile weight.

\section{Data analysis}

Data obtained were subjected to Analysis of Variance (ANOVA), using $\mathrm{SAS}^{23}$ package. Where significant differences occurred among means, Duncan Multiple Range Test ${ }^{24}$ was used to separate them.

\section{Results and discussion}

The results of the research are presented in Tables 2-4. Table 1 shows the composition of the experimental diets while Table 2 is the chemical compositions of the individual feeds. Brewers' dried grain being the supplement had a high dry matter, highest crude protein with low crude fiber. Groundnut haulms had the highest crude fibre, dry matter and Ash. However, all the feed ingredients had crude protein above the $12 \%$ minimum requirement of ruminants. ${ }^{25}$ Table 3 shows the effects of the diets on Morphometric parameters. The result shows that the heights at withers had a range of 35.79 to $46.08 \mathrm{~cm}$ with significant $(\mathrm{P}<0.05)$ difference between treatment means. This value was similar to $38.95 \mathrm{~cm}$ obtained by Bello et al. ${ }^{5}$ when they fed Savanna brown goats. Girth circumference (GC) was in the range of 22.17 to $25.96 \mathrm{~cm}$ with significant difference $(\mathrm{P}<0.05)$ among treatment means. This was lower than the range of 55.10 to $65.65 \mathrm{~cm}$ obtained by Babale et al. ${ }^{26}$ when they fed Red Sokoto male goats on replacement levels of corn cobs for maize bran with cowpea husk basal diet. The ranges for other parameters were length of animal (LA) 30.33 to $38.92 \mathrm{~cm}$, height at rump (HR) 28.25 to $39.71 \mathrm{~cm}$, abdominal circumference (AC) 18.79 to $22.29 \mathrm{~cm}$ and neck length of 13.46 to $17.79 \mathrm{~cm}$ all the results were significantly $(\mathrm{P}<0.05)$ different across treatments.

Table 2 Chemical composition of experimental feeds

\begin{tabular}{llll}
\hline Parameters & BDG & $\begin{array}{l}\text { Groundnut } \\
\text { haulms }\end{array}$ & Cowpea husk \\
\hline Dry matter (DM) \% & 90.00 & 90.89 & 85.79 \\
Crude protein (CP) \% & 19.61 & 13.58 & 16.10 \\
Crude fiber (CF) \% & 15.82 & 35.88 & 11.04 \\
Ether extract (EE) \% & 6.5 & 1.56 & 4.40 \\
Ash \% & 9.2 & 45.68 & 9.2 \\
\hline
\end{tabular}

BDG, brewers' dried grains

Table 3 Effects of diets on linear body measurements

\begin{tabular}{lllllll}
\hline Parameters & \multicolumn{2}{l}{ Treatments } & & SEM & $\begin{array}{c}\text { Sig. } \\
\text { lev }\end{array}$ \\
\cline { 2 - 5 } & $\mathbf{T}_{1}$ & $\mathbf{T}_{2}$ & $\mathbf{T}_{3}$ & $\mathbf{T}_{4}$ & & \\
\hline HW $(\mathrm{cm})$ & $35.79^{\mathrm{d}}$ & $46.08^{\mathrm{a}}$ & $45.46^{\mathrm{b}}$ & $42.96^{\mathrm{c}}$ & 0.15 & $* *$ \\
$\mathrm{GC}(\mathrm{cm})$ & $24.92^{\mathrm{b}}$ & $25.96^{\mathrm{a}}$ & $22.46^{\mathrm{c}}$ & $22.17^{\mathrm{c}}$ & 0.09 & $* *$ \\
LA (cm) & $30.83^{\mathrm{c}}$ & $38.92^{\mathrm{a}}$ & $30.33^{\mathrm{c}}$ & $34.63^{\mathrm{b}}$ & 0.12 & $* *$ \\
HR (cm) & $28.25^{\mathrm{c}}$ & $39.7 \mathrm{I}^{\mathrm{a}}$ & $31.63^{\mathrm{b}}$ & $30.33^{\mathrm{b}}$ & 0.11 & $* *$ \\
$\mathrm{AC}(\mathrm{cm})$ & $18.79^{\mathrm{b}}$ & $22.29^{\mathrm{a}}$ & $21.75^{\mathrm{a}}$ & $20.38^{\mathrm{a}}$ & 0.08 & $* *$ \\
$\mathrm{NL}(\mathrm{cm})$ & $13.46^{\mathrm{b}}$ & $14.72^{\mathrm{b}}$ & $16.33^{\mathrm{a}}$ & $17.79^{\mathrm{a}}$ & 0.07 & $* *$ \\
\hline
\end{tabular}

abc, means in the row with different superscripts differed significantly $(P<0.05)$. $\mathrm{HW}$, height at withers; GC, girth circumference; LA, length of animal; HR, height at rump; AC, abdominal circumference; NL, neck length; SEM, standard error of the mean
Table 4 Effects of diets on reproductive organ parameters

\begin{tabular}{|c|c|c|c|c|c|c|}
\hline \multirow[t]{2}{*}{ Parameters } & \multicolumn{4}{|c|}{ Treatment } & \multirow[t]{2}{*}{ SEM } & \multirow{2}{*}{$\begin{array}{l}\text { Sig. } \\
\text { lev }\end{array}$} \\
\hline & $T_{1}$ & $\mathbf{T}_{2}$ & $T_{3}$ & $\mathbf{T}_{4}$ & & \\
\hline $\mathrm{SL}(\mathrm{cm})$ & $33.04^{c}$ & $27.38^{d}$ & $35.88^{b}$ & $38.92^{\mathrm{a}}$ & 0.16 & $* *$ \\
\hline $\mathrm{SC}(\mathrm{cm})$ & $17.63^{\mathrm{a}}$ & $15.25^{\mathrm{b}}$ & $13.17^{c}$ & $12.67^{c}$ & 0.08 & $* *$ \\
\hline STW (g) & $45.67^{a}$ & $38.46^{\mathrm{b}}$ & $43.63^{\mathrm{a}}$ & $36.92^{\mathrm{b}}$ & 0.13 & $* *$ \\
\hline $\mathrm{TC}(\mathrm{cm})$ & $10.00^{\mathrm{a}}$ & $9.88^{a}$ & $8.67^{b}$ & $8.57^{b}$ & 0.04 & $* *$ \\
\hline TV (mls) & $21.08^{a}$ & $18.42^{\mathrm{a}}$ & $20.46^{a}$ & $17.88^{b}$ & 0.02 & $* *$ \\
\hline PL (cm) & $3.42^{\mathrm{b}}$ & $3.06^{c}$ & $3.33^{\mathrm{b}}$ & $4.13^{a}$ & 0.02 & $* *$ \\
\hline PW (g) & $3.79^{\mathrm{a}}$ & $3.29^{\mathrm{b}}$ & $3.46^{\mathrm{a}}$ & $3.21^{\mathrm{b}}$ & 0.02 & $* *$ \\
\hline
\end{tabular}

abc, means in a row with different superscripts differ significantly $(P<0.05)$. SEM, standard error of the mean; SL, scrotal length; SC, scrotal circumference; STW, scrotal and testicular weight; TC, testicular circumference; TV, testicular volume; PL, penile length, PW, penile weight

Effects of the diets on reproductive organ parameters are presented in Table 4. Results revealed that scrotal lengths (SL) varied from 27.38 to $38.92 \mathrm{~cm}$ with significant difference $(\mathrm{P}<0.05)$ across treatments. Rekik et al. ${ }^{27}$ reported that in males, reproductive function in young animals appears to be more susceptible to dietary restrictions of energy and protein than in adult and may lead to permanent histological changes at the level of the testis. Scrotal circumference (SC) ranging from 12.67 to $17.63 \mathrm{~cm}$ is reported in this experiment which differed $(\mathrm{P}<0.05)$ significantly across treatments. These values are similar to 17.82 to $19.91 \mathrm{~cm}$ reported by Abba \& Igbokwe ${ }^{19}$

Scrotal and testicular weights (STW) result ranged from 36.92 to $45.67 \mathrm{~g}$ with significant $(\mathrm{P}<0.05)$ difference among treatment means. For the testicular circumference (TC), values ranged from 8.57 to $10.00 \mathrm{~cm}$ which were significantly $(\mathrm{P}<0.05)$ different across treatments. These values are similar to 8.39 to $9.89 \mathrm{~cm}$ reported Abba $\&$ Igbokwe $^{19}$ for Nigerian Sahel goats. The result could be due to the fact that the animals are immature and so the scrotal circumference has not yet developed. According to Schoenian ${ }^{28}$ and Neary ${ }^{29}$ scrotal circumference (SC) measurement can be taken along with the palpation of the testicle area as part of breeding soundness evaluation. Testicular volumes obtained ranged from 17.88 to $21.08 \mathrm{mls}$ which also differed significantly $(\mathrm{P}<0.05)$ across treatments.

These results are in agreement with Nasir et al..$^{30}$ who reported that testicular morphometry showed significant effect $(p<0.05)$ in all the parameters observed when they offered Red Sokoto Bucks Cotton Seed Cake. For penile morphometry, the results ranged from 3.06 to $4.13 \mathrm{~cm}$ for penile length (PL) and 3.21 to $3.79 \mathrm{~g}$ for penile weights respectively. All parameters differed $(\mathrm{P}<0.05)$ significantly across treatments.

\section{Conclusion and recommendations}

It was clear from this study that diets showed some positive effects on reproductive organ morphometry of West African Dwarf goats. This study therefore leads us to recommend that the suitability of testicular and scrotal measurements as criteria for early selection of male goats should be emphasized and therefore the animals be fed adequately.

\section{Acknowledgements}

None. 


\section{Conflict of interest}

The authors declare there is no conflict of interest.

\section{References}

1. Adejoro FA, Salako AE, Ogundere AA. Phenotypic characterization of the balami sheep in Nigeria. Proceedings of the 15th Annual conference of Animal Science Association of Nigeria (ASAN); 2010 Sep 13-16; University of Uyo. Nigeria; 2012.

2. Samuel OKF, Salako AE. Body Measurements characteristics of the West African Dwarf goats in Deciduous forest zone of South Western Nigeria. Afr J Biotechnol. 2008;7(14):2521-2526.

3. Akpa GN, Suleiman IO, Alphonsus C. Effect of Age, Hair type and Body Condition score on body conformation traits in Yankasa Rams. Nigerian Journal of Animal Science. 2011;13:23-28.

4. Adewumi OO, ES Adewole. Milk off take of Dam, Neck and Cephalic Measurements in Lambs and kids under traditional system of Management. Proceedings of the 16th Annual Conference of Animal Science Association of Nigeria (ASAN); 2011 Sep 12-15; Kogi State University, Ayingba, Nigeria; 2012.

5. Bello A, Adamu YA, Umaru MA, et al. Morphometric analysis of the reproductive system of African zebu cattle. Scientific Journal of Zoology. 2012;1(2):31-36.

6. Perumal P. Scrotal circumference and its relationship with testicular growth, age and body weight in Tho Tho (Bos indicus) Bulls. Int Sch Res Notices. 2014;2014:249537

7. Salhab SA, Zarkawi M, Wardeh MF, et al. Development of testicular dimensions and size and their relationships to age, body weight and parental size in growing Awasi ram lambs. Small Ruminants Research. 2001;40(2):187-191.

8. Kaymakci M, Sarican C, Karaca O. Investigations on the testis characteristics in male lambs Ege University Ziraat Faluttesi. 2008;25:109-123.

9. Devkota B, Koseki M, Matsui M. Relationships among age, body weight, Scrotal circumference scrotal circumference, semen quality and peripheral testosterone and estradiol concentration in prepubertal and post pubertal Bulls. J Vet Med Sci. 2008;70(1):119-121.

10. Coulter GH, Forte RH. Relationship of body weight to testicular size and consistency in growing Holstein Bulls. Journal of Animal Science. 1977;44(6):1076-1079.

11. Waldner CL, Kennedy RI, Palmer CW. A description of the findings from bull breeding soundness evaluations and their associations with pregnancy outcomes in a study of Western Canadian Beef herds. Theriogenology. 2010;74(5):871-883.

12. Jennifer MB. Data collection and Interpretation, In: Beef Sire Selection Manual National Beef Cattle Evaluation Consortium. Colorado State University; 2013:33-34.

13. Rumph JM. Expected Progeny Difference. In: Beef Sire Selection Manual National Beef Cattle Evaluation Consortium. Colorado State University; 2013:36-40.

14. Parker R, Mathis C, Hawkins D. Evaluating the breeding soundness of Beef Bulls GuideB-216. Mexico State University: USA; 2004.
15. Pillar S, Placin I, Yaniz J. Management factors affecting fertility in sheep. 2015.

16. Ugwu SOC. Relationship between scrotal circumference, in situ testicular measurements and sperm reserves in the West African dwarf bucks. African Journal Biotechnology. 2009;8(7):1354-1357.

17. Martin GB, Greeff JC. Genetic frontiers in the development of 'clean, green and ethical' management systems for the extensive sheep industry. Proceedings of Association of Advanced Animal Breeding Genetics. 2011;19:143-150.

18. Duguma G, Cloete SWP, Schoeman SJ, et al. Genetic parameters of testicular measurements in Merino rams and the influence of scrotal circumference on total flock fertility. South African Journal of Animal Science. 2002;32(2):123-131.

19. Abba Y, Igbokwe IO. Testicular and related size evaluations in Nigerian sahel goats with optimal cauda epididymis sperm. Reserve. Veterinary Medicine International. 2015;2(3):35-40.

20. Saidu I, Gadiga BL. Population: A write up. In: Adebayo AA, editor Mubi region a geographic synthesis. Department of geography, Federal University of Technology, Paraclette Publishers: Yola, Nigeria; 2004:117-119.

21. Areola OO. Soil and vegetable resources. In: Geography of Nigeria Dev Heinemann; Ibadan, Nigeria; 1983:26-40.

22. Adebayo AA. Mubi Region: A geographical synthesis. Department of Geography, Federal University of Technology, Paraclette Publishers: Yola, Nigeria; 2004:32-33.

23. SAS. Statistical Analysis System, SAS 2001, SAS/STAT Software Release 802, SAS Institute Inc Cary, NC USA, 2001

24. Duncan DB. Multiple Ranges and multiple F-tests Biometrics. International Biometric Society. 1955;11:1-42.

25. Devendra C, Mcleroy GB. Goat and Sheep production in the tropics. Intermediate Tropical Agriculture series, Longman, Scientific and technical, Singapore. Commonwealth agricultural Bureau. Fanham House; UK. 1987:90-115

26. Babale DM, Kibon A, Yahaya MS. Performance and linear body measurements of Red Sokoto male goats on replacement levels of corn cobs for maize bran with cowpea husk basal diet. Net Journal of Agricultural Science. 2015;3(2):35-40.

27. Rekik M, Lassoued N, Ben Salem H, et al. Interactions between nutrition and reproduction in sheep and goats with particular reference to the use of alternative feed sources In: Priolo A, Biondi L, Ben Salem H, editors. Advanced nutrition and feeding strategies to improve sheep and goat. Zaragoza, CIHEAM; 2007:375-383.

28. Schoenian S . Sheep 201 Beginners guide to raising sheep . 2012.

29. Neary M. Reproductive management of the Ewe flock and the ram. 2014.

30. Nasir M, Njidda AA, Duwa H et al. Testicular morphometry of red sokoto bucks fed cotton seed cake. Sch J Agric Vet Sci. 2014;1(4A):242-248. 